\title{
FARMERS' PERCEPTION OF SIMPLE MECHANIZED FARM IMPLEMENTS USED IN CROP PRODUCTION IN ABIA STATE, NIGERIA
}

\author{
C. U. Nwaobiala ${ }^{1}$ and C. I. Ezeh $^{2}$
}

\begin{abstract}
Farmers'Perception of simple mechanized farm implements (Knapsack Sprayer, Watering Can and Sickle) used in crop production in Abia State, Nigeria were analyzed in 2009. A multistage random sampling technique was used to select 180 crop farmers. The probit regression model result showed that the critical determinants of farmers Perception include such attributes as labour saving advantage and improvement of product quality of Knapsack, which were signifcant at 5\% probability level, while time saving advantage influenced the use of watering can at $5 \%$ risk level of probability. Also, attributes such as simplicity of implement and accessibility of implement encouraged farmers perception in the use of sickle at $5 \%$ and $1.0 \%$ level of probability respectively. It is therefore recommended that fabricators should produce implements that have the attributes of time and labour saving advantages.
\end{abstract}

Keywords: Perception, simple mechanized farm implements, crop production.

\section{INTRODUCTION}

Agriculture has been described as the mainstay of economic growth in Nigeria, sustaining 90 percent and 70 percent of the rural and total labour force respectively (Akpabio, 2005). Haque et al (2001), stated that the rate of growth in food production in the country was $2.5 \%$ per annum, compared to the alarming rate of population growth of about $5-7 \%$. This is occasioned by the low level of agricultural mechanization. This situation is worsened by the small holdings of less than 2 hectares scattered over a large area of land in Nigeria (Okunenye, 1993). However, Alabi (2006) affirmed that problems of shortage of farm power, land tenure systems and bad rural transportation had incapacitated the production of large quantities of farm produce. For agricultural sector of the Nigerian economy to meet its objective of sustainable food and economic development, it needs to be mechanized (Enya and Alimba, 2008). Mechanization is the use of all tools and implements that help the farmer to use his muscle to a better advantage. In other words, agricultural mechanization is a means of easing human tools in agricultural operation and providing man with time for other activities (Anazodo, 1990). According to Idike (2008), small scale farm machinery required in the country include those that promote and facilitate timeliness of field operations and activities. Presently, human muscles supply over $95 \%$ of the energy needed on farms leading to low output, high cost of labour as well as poor standard of living among the Nigeria Peasant Farmers. This however calls for the introduction of much needed mechanical engine powered technology for agricultural intensification (Kalu, 1990). In Nigeria, the contribution of engine power in overall agricultural production is only $2 \%$ compared to $80 \%$ and $90 \%$ from animal and human power respectively (Odoigboh and Onwualu, 1994). Hence, there is urgent need to arrest the problem of shortage of farm labour in order to increase the rate of growth in food production, particularly by boosting the level of using simple mechanized implements in overall agricultural production (Alabi, 2008). Iwuala (2007), noted that researchers, engineers, extension workers and farmers have been identified to

\footnotetext{
${ }^{1}$ Department of Agricultural Extension and Management, Federal College of Agriculture, 159 Ishiagu, Ebonyi State.

${ }^{2}$ Department of Agricultural Economics and Extension, Abia State University, Umuahia Campus, Umuahia, Abia State.
} 
be most significant actors in efficient management of acquired technologies. Farmers' perception on agricultural power and technology is still negative and not well documented. The reason for this negativity is attributed to power awareness, low technical competence, structure of land tenure system and poor support from financial institutions (Amadi and Oguzor, 2009). Ngoddy (1990), points out that among the constraints to agricultural mechanization in the tropics are lack of sustainability and adaptability of machines and equipment manufactured in the industrialized countries to the tropical systems. It is against this background that this paper seeks to analyze farmers perceptions of simple mechanized implements used in crop production in Abia State, Nigeria.

Therefore, the specific objectives are to:

i. examine farmers perception of the attributes of knapsack, watering can and sickle used in crop production in Abia State.

ii. determine the influence of farmers perception on the attributes of simple mechanized farm implements used in crop production in Abia State.

In order to achieve the specific objectives, the following hypothesis is tested

1. There is no relationship between farmers' perception and the attributes of simple mechanized farm implements.

\section{MATERIALS AND METHODS}

The study area was Abia State, which is one of the south eastern states of Nigeria. The State lies in the North of the equator between latitude $5^{0} 47^{\mathrm{I}}$ and $6^{0} 12^{\mathrm{I}}$ and longitude $7^{0} 23^{\mathrm{I}}$ and $8^{0} 02^{\mathrm{I}}$ East of Greenwich meridian. Abia State is bounded in the east by Cross River State and Akwa Ibom State on the west. The State shares boundaries with Imo State on the North with Ebonyi and Enugu States, while on the South with Rivers State. The Agricultural Zones namely Umuahia, Ohafia and Aba were involved in the study. A multi-stage random sampling technique was used in the selection of agricultural blocks, circles and crop farmers. First, two (2) blocks were randomly selected from each of the zones namely Ikwuano and Isiala Ngwa North (Umuahia zone); Arochukwu and Bende (Ohafia zone) and Osisioma and Ugwunagbo (Aba zone), this gave a total of 6 blocks. Also, three (3) circles each were randomly selected from the selected blocks and this gave a total of eighteen (18) circles. Finally, ten (10) crop farmers were randomly selected from each circle, this gave a grand sample size of one hundred and eighty (180) crop farmers. The various analyses include the use of frequency counts, percentages and probit regression model. The probit regression model was employed to achieve objective 2 .

The model adopted in this paper followed that of Ekwe et al (2008), which is presented thus;

$\mathrm{Y} 1 *=\mathrm{B}^{\mathrm{t}} \mathrm{Xi}+\mathrm{E}$ where as

$\mathrm{Yi}=0$ if $\mathrm{Yi}^{*} \leq 0$

And $\mathrm{Yi}=1$ if $\mathrm{Yi}^{*}>0$

Where

$\mathrm{Yi}^{*}$ is an underlying latent variable that indicates perception of the implements.

Yi is an observable dummy variable that indicates use of implement (Used $=1$, not used $=0$ ).

$\mathrm{Bt}$ is the vector estimated parameters

$\mathrm{Xi}$ represents the implement attributes specified as

$\mathrm{X}_{1}=$ Simplicity of implement

$\mathrm{X}_{2}=$ Time saving advantage

$\mathrm{X}_{3}=$ Labour saving advantage

$\mathrm{X}_{4}=$ Improvement of product quality

$\mathrm{X}_{5}=$ Accessibility of implement. 


\section{RESULTS AND DISCUSSION}

Table 01 shows farmers perception of knapsack sprayer, watering can and sickle. The study revealed that $66.41 \%$ and $64.18 \%$ of the farmers perceived that knapsack and watering can were time saving, while $55.40 \%$ had negative perception that sickle was not time saving. Furthermore, $64.69 \%$ of the farmers perceived knapsack sprayer to be labour saving, while $55 \%$ and $50.221 \%$ of the farmers perceived knapsack sprayer and watering can to improve quality of their farm produce and $73 \%$ of them had negative perception of sickle. The study also indicated the implements that were accessible to include knapsack sprayer (31.85\%), watering can $(65.84 \%)$ and sickle $(85 \%)$. This result is in consonance with Ekwe et al (2008), where they observed that these attributes encouraged farmers in the adoption of National Root Crop Research Institute Umudike/International Institute for Tropical Agriculture, Ibadan (NRCRI/IITA) improved Gari processing technology in south eastern Nigeria.

The result of the probit regression analysis is shown in Table 02. The table showed that there was a very high degree of confidence and goodness of fit displayed by this model. This is shown by the significance level ( $\mathrm{P}<$ 0.01 ) of all the equations, Pearson goodness of fit chi-square.
This indicates that any of the functional probit equation can be used for predictive purposes. The coefficient (0.00179) of labour savings advantage attributes and improved quality (0.00246) in the knapsack sprayer equation were positive and statistically significant at 95.0\% confidence level. This implies that the greater the labour savings attributes and improvement in product quality, the higher the farmers perception in the use of these implements in crop production. This signs of the attributes were in consonance with a prior expectation. This result is consistent with Ekwe et al (2008), who obtained similar result.

The coefficient (0.00132) of simplicity of implement attributes and accessibility of implement $(0.00476)$ in the sickle equation were positive and statistically significant at $5.0 \%$ and $1.0 \%$ risk level. The sign of the variable is consistent with a prior expectation. This implies that the greater the simplicity attributes and accessibility of implement, the higher the farmers' perception in the use of these implements in crop production, especially in harvesting of rice and forage for livestock production.

Table 01: Percentage distribution of farmers perception according to the attributes of simple mechanized farm implements in Abia State, Nigeria. $(\mathrm{N}=180$ respondents)

\begin{tabular}{|c|c|c|c|c|c|c|c|}
\hline \multirow{2}{*}{ Attributes of Implement } & \multicolumn{2}{|c|}{ Knapsack sprayer } & \multicolumn{2}{|c|}{ Watering can } & \multicolumn{3}{|l|}{ Sickle } \\
\hline & Positive & Negative & Positive & Negative & Positive & Negative & Total \\
\hline Simplicity of Implement & 75.00 & 25.00 & 50.00 & 50.00 & 70.00 & 30.00 & 100 \\
\hline Time Saving Advantage & 66.41 & 33.59 & 64.18 & 35.82 & 44.60 & 55.40 & 100 \\
\hline Labour Saving Advantage & 64.69 & 35.31 & 50.00 & 45.00 & 50.00 & 47.00 & 100 \\
\hline $\begin{array}{l}\text { Improvement of Product } \\
\text { Quality }\end{array}$ & 55.00 & 45.00 & 50.21 & 49.79 & 27.00 & 73.00 & 100 \\
\hline Accessibility of Implement & 31.85 & 68.15 & 65.84 & 34.84 & 85.00 & 15.00 & 100 \\
\hline
\end{tabular}

Source: Field Survey Data, 2009 
Table 02: Probit regression model estimation of relationship between farmers perception of simple mechanized farm implements.

\begin{tabular}{|c|c|c|c|c|c|c|}
\hline \multirow[t]{2}{*}{ Variables } & \multicolumn{2}{|c|}{ Knapsack sprayer } & \multicolumn{2}{|c|}{ Watering can } & \multicolumn{2}{|l|}{ Sickle } \\
\hline & Coefficient & t-ratio & Coefficient & t-ratio & Coefficient & t-ratio \\
\hline $\begin{array}{l}\text { Simplicity of Im- } \\
\text { plement }\end{array}$ & -0.10607 & 0.96573 & .000163 & -0.00867 & 0.00132 & $2.0270 * * *$ \\
\hline $\begin{array}{l}\text { Time Saving Ad- } \\
\text { vantage }\end{array}$ & -0.01316 & -0.18982 & 0.0073 & $2.03783 * *$ & -0.07505 & 1.25757 \\
\hline $\begin{array}{l}\text { Labour Saving } \\
\text { Advantage }\end{array}$ & 0.00179 & $2.02856 * *$ & 0.18931 & -009931 & 0.07885 & 1.38387 \\
\hline $\begin{array}{l}\text { Improvement of } \\
\text { Product Quality }\end{array}$ & 0.00246 & $2.03994 * *$ & 0.01871 & 0.09329 & 0.01259 & 4.26145 \\
\hline $\begin{array}{l}\text { Accessibility of } \\
\text { Implement }\end{array}$ & 0.01501 & -0.24695 & 0.03420 & 0.18217 & 0.00476 & $3.09891 * *$ \\
\hline Constant & \multicolumn{2}{|c|}{-2.85535} & \multicolumn{2}{|c|}{-2.62342} & \multicolumn{2}{|c|}{-3.04503} \\
\hline $\begin{array}{l}\text { Pearson Goodness } \\
\text { of Fit X }{ }^{2}\end{array}$ & \multicolumn{2}{|l|}{$206.468 * * *$} & \multicolumn{2}{|c|}{$173.030 * * *$} & \multicolumn{2}{|c|}{$251.135 * * *$} \\
\hline
\end{tabular}

Source: Field Survey Data, $2009 * *$ Significant at $5 \%, * * *$ Significant at $1 \%$

\section{CONCLUSIONS}

Based on the findings, it has been established that farmers use of knapsack sprayer was encouraged by the perception that the implement was labour saving and improves the quality of harvested products. Also, farmers use of watering can was encouraged by the perception that the implement was time saving and improvement of product quality, while farmers used sickle because of simplicity and accessibility of the implements.

In view of the above, the following recommendations are proffered:
1. Input agencies should make these readily available and affordable to farmers.

2. Farmers should be trained on the application and use of these implements in crop production.

3. There is need to promote and popularize the use of knapsack sprayer and watering can.

4. Fabricators should produce implements that have the attributes of time and labour saving advantages.

\section{REFERENCES}

Akpabio, I. (2005). Human Agriculture, Social Themes in Agricultural Development. Abam Publishing Company, Uyo, Akwa Ibom State Nigeria.

Alabi, K. M. (2008). Farmers Access to Public Tractor Hiring Services in Osun State, Nigeria. Nigerian Journal of Rural Sociolog, 8(1): 71-78.

Amadi, N.S. and Oguzor, N.S. (2009). Impediments to Extending Agricultural Power and Technology to Small Scale Farmers in Nigeria Delta of Nigeria. Nigeria Journal of Rural Sociology 9 (1): 59-63. 